\title{
Thermal Response of Scented Rice under Different Weed Management Practices in Organic Production System
}

\author{
Prajapat Rohit, Mishra Priyanka, B.M. Maurya and S.M. Kurmvanshi* \\ All India Coordinated Research Project on Farming System, Kuthulia farm JNKVV, college of \\ agriculture, Rewa (M.P) 486001, India \\ *Corresponding author
}

\section{A B S T R A C T}

\begin{tabular}{|c|c|}
\hline $\begin{array}{l}\text { Ke y w o r d s } \\
\text { Cropping system, } \\
\text { Organic rice and } \\
\text { Weed control }\end{array}$ & $\begin{array}{l}\text { A field experiments on evaluation of weed management practices in scented rice under } \\
\text { organic production system was conducted during } 2017-18 \text { and } 2018-19 \text { at All India } \\
\text { Coordinated Research Project on Farming System, Rewa (M.P). The study reveals that } \\
\text { weed control efficiency and grain yield of rice were maximum under incorporation of }\end{array}$ \\
\hline Article Info & and $\mathrm{B}: \mathrm{C}$ ratio were maximum under $2 \mathrm{HW}$ at 25 and $50 \mathrm{DAT}$ followed by mulching with \\
\hline $\begin{array}{l}\text { Accepted: } \\
15 \text { February } 2019 \\
\text { Available Online: } \\
10 \text { March } 2019\end{array}$ & $\begin{array}{l}\text { gave B:C ratio more than } 2 \text {. Heat use efficiency was maximum } 7.94 \mathrm{~kg} / \mathrm{ha} \text { per GDD under } \\
\text { incorporation of mustard oil cake @ 5t/ha with one hand weeding followed by } 2 \mathrm{HW} \text { at } 25 \\
\text { and } 50 \text { DAT. }\end{array}$ \\
\hline
\end{tabular}

\section{Introduction}

Rice is a major crop of rice- wheat crop zone of Madhya Pradesh which occupies an area of 19.3 lakh hectares with the production of 27.8 lakh tonnes and average productivity of 1440 $\mathrm{kg} / \mathrm{ha}$. Rice crop is sensitive to temperature and weed infestation which greatly influenced the growth, yield and heat use efficiency of rice crop. Organic farming is a production system that avoides the use of synthetic chemical fertilizer, pesticides and growth regulating hormones and raises the crop with the use of organic manures, bio-fertilizers, oilcake, crop rotation, legumes, green manure and biological pest control in rice. Organic farming is not feasible in modern commercial agriculture because it is unable to sustain high level of production to need the food grain supply for the ever increasing population (Tarafdar et al., 2008). Weeds become most limiting factor in organic farming which affect the yield and heat use pattern of rice. None of the cultural practices has been found effective to reduce the weed problem in rice under organic production system and grain yield of rice reduced by 57 to $61 \%$ (Mukherjee et al., 2008). Some cultural practices like intercropping of dhaincha in rice, close row spacing or high seed rate, stale seed bed, 
mulching by crop residues or tree leaves, hand weeding and hoeing are being found effective to reduce the weed problem under organic rice production system. Any practices aimed at enhancing competitive availability of the crop and weed can bring down the adverse effect of weed on rice. Seedling vigour, early growth rate, tillering ability, stale seed bed, higher fertilizers dose, hoeing and mulching can give competitive advantage to the crop.

Use of mustard oil cake at higher level has been found beneficial as it increases the growth character of rice which has ability to suppress the weed growth (Islam et al., 2007). Intercropping suppress weeds better then sole cropping and thus provides an opportunity to utilize crop themselves as tools for weed management (Rao and Shetty 1976). Cultivation of rice at narrow/close row spacing has been found effective to reduce the weed growth and increase the rice yield as compared to wider spaced rice crop (Bhan 1968).

In past, degree day techniques have been variously applied to correlate the phenological development of rice crop.

However, phenology ambient temperature interaction of rice crop under different weed control practices in organic production system has not been studied. Keeping above facts in view the present experiment was taken.

\section{Materials and Methods}

The present experiment was taken on silty clay loam soil of All India coordinated research project on farming system, Kuthulia farm JNKVV, college of agriculture, Rewa during kharif season of 2017-18 and 2018-19. The experimental field was low in available nitrogen $(180.31 \mathrm{~kg} / \mathrm{ha})$, medium in available phosphorus $(16.93 \mathrm{~kg} / \mathrm{ha})$ and high in available potash $(283.6 \mathrm{~kg} / \mathrm{ha})$. The cropping system was rice- garlic. The scented variety of rice PS-5 was transplanted 8 and 9 July in 2017 and 2018, respectively. Two seedlings per hill were transplanted at the planting geometry of $20 \mathrm{~cm} \times 15 \mathrm{~cm}$ in all the plots and in $\mathrm{T} 4$ at $15 \mathrm{~cm} \times 15 \mathrm{~cm}$. The plot size was $5 \mathrm{~m} \times 4.2 \mathrm{~m}$. The weed control treatments were $\mathrm{T}_{1}-2$ Hand wedding 25 and 50 DAT, $\mathrm{T}_{2^{-}}$ conoweeder at $25 \mathrm{DAT}+$ one hand wedding at $50 \mathrm{DAT}, \mathrm{T}_{3}$ - Intercropping with dhaincha in rice, $\mathrm{T}_{4}$-stale seed bed+reduced spacing up to $25 \%+$ mulching with wheat straw+ one hand wedding, $\mathrm{T}_{5^{-}}$locally available weed mulch+one hand pulling, $\mathrm{T}_{6}$ - Incorporation of mustard oil cake 15 days before transplanting @ 5t/ha $+1 \mathrm{HW}$ and $\mathrm{T}_{7}$-ITK treatment on weed control practiced by farmers as mulching with leaf of mango under organic production system. The experimental design was RBD with three replication.

Dates were recorded for panicle emergence and maturity of crops. The growing degree days were calculated using $10^{\circ} \mathrm{c}$ as base temperature and accumulated over the different growth stages (Iwata 1975, Nuttosson, 1955 and Shastry and Chakravorty 1982). Photothermal units (PTU) were calculated by multiplying growing degree days (GDD) today length. Heat use efficiency (HUE) for different stages was evaluated using above ground biomass and grain yield. The phenothermal index was also calculated by following Nuttonson (1955) and Shastry and Chakravorty (1982).

\section{Results and Discussion}

\section{Phenology}

Data pertaining to occurrence of phenological events of scented rice crop under the influence of different weed control practices in organic production system is presented in Table 1. It is evident from the result that early panicle emergence and maturity of rice were observed 
under two hand weeding at 25 and 50 DAT followed by Incorporation of mustard oil cake @ 5t/ha+ 1HW. Panicle emergence and maturity of rice were delayed under stale seed bed and reduced spacing upto $25 \%+$ one hand weeding and in intercropping with dhaincha in 3:1 row system.

Energy summation indices during crop growth period Growing degree days

The data presented in Table 1. In respect to growing degree days (GDD) reveals that higher growing degree days (GDD) were required under stale seed bed+reduced spacing upto $25 \%+$ one hand weeding at 50 DAT followed by intercropping of dhaincha with rice in 1:3 row system as weed control practices. GDD requirement (2054 GDD) was lower under two hand weeding at 25 and 50 DAT and incorporation of mustard oil cake @ $5 \mathrm{t} / \mathrm{ha}+1 \mathrm{HW}$. It may be due better weed control efficiency of these treatments in scented rice PS-5.

\section{Photothermal units}

The photothermal unit (PTU) for sowing to panicle emergence and sowing to maturity stage under different weed control practices in organic rice production system have been presented in Table 1 reveals that requirements of PTU were higher in the treatments in which weed control efficiency was poor like stale seed bed+reduced spacing upto $25 \%+1 \mathrm{HW}$ and intercropping of dhaincha with rice in 1:3 row system. The treatments having better growth and weed control efficiency have lower PTU requirements such as two hand weeding at 25 and 50 DAT and incorporation of mustard oil cake@5t/ha+1 HW.

\section{Phenothermal indices}

Degree day utilization rates per day between different phenological stages were computed and have been presented in Table 1. It is evident that phenothermal indices were higher during sowing to panicle emergence stage of rice as compared to sowing to maturity stage.

It may be due to continuous decrease in temperature during September and October. The value of phenothermal indices during sowing to panicle emergence and sowing to maturity stage were not affected significantly due to different weed control treatments given in organic rice production.

\section{Heat use efficiency}

Heat use efficiency for grain and biomass yield of rice under different weed control practices under organic production system have been presented in Table 2. After perusal of result it is clear that heat use efficiency of biomass was higher than grain yield of rice.

Lowest heat use efficiency $5.7 \mathrm{~kg}$ biomass/ha per GDD was noted under intercropping of dhaicha with rice in 1:3 row system. It may be due to replacement of $25 \%$ rows of rice by dhaicha by which yield was reduced.

Maximum heat use efficiency $7.94 \mathrm{~kg} / \mathrm{ha}$ per GDD was noted under incorporation of mustard oil cake $5 \mathrm{t} /$ ha with one hand weeding given at 25 DAT followed two hand weeding given at 25 and 50 DAT. Heat utilization efficiency by rice grain was significantly low $1.68 \mathrm{~kg} / \mathrm{ha}$ per GDD under farmers practice of mulching of mango leaves for weed control followed by intercropping of dhaincha with rice in 1:3 row system.

The heat use efficiency were higher under two hand weeding at 25 DAT and 50 DAT and incorporation of mustard oil cake 5 t/ha+one hand weeding. It may be due higher weed control efficiency and lower infestation of weeds in rice field under these treatments. 
Table.1 Number of days taken, growing degree days, photothermal and phenothermal units of rice as influenced by weed control practices under organic production system

\begin{tabular}{|c|c|c|c|c|c|c|c|c|}
\hline \multirow[t]{2}{*}{ Treatment } & \multicolumn{2}{|c|}{ Number of days taken } & \multicolumn{2}{|c|}{ Growing degree days } & \multicolumn{2}{|c|}{$\begin{array}{l}\text { Photothermal unit at different } \\
\text { stages }\end{array}$} & \multicolumn{2}{|c|}{$\begin{array}{c}\text { Phenothermal } \\
\text { indices degree days / } \\
\text { growth days }\end{array}$} \\
\hline & $\mathrm{S}-\mathrm{P}_{\mathrm{E}}$ & S-M & $\mathrm{S}-\mathrm{P}_{\mathrm{E}}$ & S-M & $\mathrm{S}-\mathrm{P}_{\mathrm{E}}$ & S-M & $\mathrm{S}-\mathrm{P}_{\mathrm{E}}$ & S-M \\
\hline $\begin{array}{l}T_{1} \text { Two hand weeding } 25 \text { and } \\
50 \text { DAT }\end{array}$ & 80.3 & 108.3 & 1550 & 2054 & 14024 & 18185 & 19.30 & 18.96 \\
\hline $\begin{array}{l}\mathrm{T}_{2} \text { Cono weeder } 25 \mathrm{DAT}+ \\
\text { one HW at } 50 \text { DAT }\end{array}$ & 82.3 & 109.3 & 1585 & 2071 & 14320 & 18321 & 19.25 & 18.94 \\
\hline $\begin{array}{l}\mathbf{T}_{3} \text { Inter cropping with } \\
\text { Dhaincha }\end{array}$ & 83.0 & 113.3 & 1600 & 2131 & 14444 & 18810 & 19.27 & 18.80 \\
\hline $\begin{array}{l}\mathbf{T}_{4} \text { Stale seed bed + reduced } \\
\text { spacing up to }(25 \%)+ \\
\text { mulching with wheat straw + } \\
\text { one hand weeding }\end{array}$ & 86.3 & 114.3 & 1654 & 2146 & 14892 & 18938 & 19.16 & 18.77 \\
\hline $\begin{array}{l}T_{5} \text { Locally available weed } \\
\text { mulch }+1 \text { hand pulling }\end{array}$ & 86.6 & 109.3 & 1550 & 2071 & 14024 & 18321 & 19.23 & 18.94 \\
\hline $\begin{array}{l}T_{6} \text { Incorporation of mustard } \\
\text { oil cake } 15 \text { days before } \\
\text { sowing @ } 5 \mathrm{t} / \mathrm{ha}+1 \mathrm{HW}\end{array}$ & 81.3 & 109.3 & 1568 & 2071 & 14171 & 18321 & 19.28 & 18.94 \\
\hline $\begin{array}{l}T_{7} \text { ITK treatment on weed } \\
\text { control practices by farmers } \\
\text { as mulching with leaf on } \\
\text { mango }\end{array}$ & 82.3 & 109.6 & 1585 & 2071 & 14320 & 18321 & 19.25 & 18.88 \\
\hline
\end{tabular}

$\mathrm{S}-\mathrm{P}_{\mathrm{E}}=$ Sowing to panicle emergence

$\mathrm{S}-\mathrm{M}=$ Sowing to maturity 
Table.2 Heat use efficiency of rice as influenced by different weed control practices under organic production system

\begin{tabular}{|c|c|c|c|c|c|c|}
\hline \multirow[t]{2}{*}{ Treatment } & \multicolumn{3}{|c|}{$\begin{array}{l}\text { Heat use efficiency by biomass } \mathrm{kg} / \mathrm{ha} / \mathrm{GDD} \text { at sowing to } \\
\text { maturity }\end{array}$} & \multicolumn{3}{|c|}{$\begin{array}{l}\text { Heat use efficiency by grain } \mathrm{kg} / \mathrm{GDD} / \mathrm{ha} \\
\text { Sowing to maturity }\end{array}$} \\
\hline & $\begin{array}{l}\text { Year } \\
2017\end{array}$ & $\begin{array}{l}\text { Year } \\
2018\end{array}$ & Mean & $\begin{array}{l}\text { Year } \\
2017\end{array}$ & $\begin{array}{l}\text { Year } \\
2018\end{array}$ & Mean \\
\hline $\begin{array}{l}T_{1} \text { Two hand weeding } 25 \text { and } \\
50 \text { DAT }\end{array}$ & 5.83 & 8.12 & 6.97 & 2.14 & 2.89 & 2.51 \\
\hline $\begin{array}{l}\mathrm{T}_{2} \text { Cono weeder } 25 \text { DAT + one } \\
\text { HW at } 50 \text { DAT }\end{array}$ & 7.05 & 6.56 & 6.80 & 1.98 & 2.33 & 2.15 \\
\hline $\begin{array}{l}\mathbf{T}_{3} \text { Inter cropping with } \\
\text { Dhaincha }\end{array}$ & 6.30 & 5.19 & 5.74 & 1.76 & 1.82 & 1.79 \\
\hline $\begin{array}{l}\mathbf{T}_{4} \text { Stale seed bed + reduced } \\
\text { spacing up to }(25 \%)+ \\
\text { mulching with wheat straw + } \\
\text { one hand weeding }\end{array}$ & 5.99 & 5.80 & 5.89 & 1.97 & 2.06 & 2.01 \\
\hline $\begin{array}{l}T_{5} \text { Locally available weed } \\
\text { mulch }+1 \text { hand pulling }\end{array}$ & 6.48 & 6.55 & 6.51 & 2.26 & 2.28 & 2.27 \\
\hline $\begin{array}{l}\text { T}_{6} \text { Incorporation of mustard oil } \\
\text { cake } 15 \text { days before sowing @ } \\
5 t / h a+1 H W\end{array}$ & 8.74 & 7.15 & 7.94 & 2.64 & 2.59 & 2.61 \\
\hline $\begin{array}{l}T_{7} \text { ITK treatment on weed } \\
\text { control practices by farmers as } \\
\text { mulching with leaf on mango }\end{array}$ & 6.77 & 5.02 & 5.89 & 1.72 & 1.64 & 1.68 \\
\hline $\mathbf{S}_{\mathbf{E}} \mathbf{M}_{\underline{ \pm}}$ & 0.32 & 0.36 & 0.34 & 0.05 & 0.10 & 0.07 \\
\hline CD at $\overline{5} \%$ & 1.00 & 1.13 & 1.04 & 0.17 & 0.32 & 0.21 \\
\hline
\end{tabular}


Table.3 grain and straw yield of riceas influenced by different weed management practices under organic production system

\begin{tabular}{|c|c|c|c|c|c|c|}
\hline \multirow[t]{2}{*}{ Treatment } & \multicolumn{3}{|c|}{ Straw yield $q / h a$} & \multicolumn{3}{|c|}{ Grain yield q/ha } \\
\hline & $\begin{array}{l}\text { Year } \\
2017\end{array}$ & $\begin{array}{l}\text { Year } \\
2018\end{array}$ & Mean & $\begin{array}{l}\text { Year } \\
2017\end{array}$ & $\begin{array}{l}\text { Year } \\
2018\end{array}$ & Mean \\
\hline $\begin{array}{l}\text { T } 1 \text { Two hand weeding } 25 \text { and } 50 \\
\text { DAT }\end{array}$ & 100.98 & 107.28 & 104.13 & 46.87 & 59.63 & $\begin{array}{c}53.25 \\
(53.90 \%)\end{array}$ \\
\hline $\mathrm{T}_{2}$ Cono weeder $25 \mathrm{DAT}+$ one & 104.34 & 87.40 & 95.87 & 41.80 & 48.52 & 45.16 \\
\hline$T_{3}$ Inter cropping with Dhaincha & 96.76 & 71.91 & 84.33 & 37.70 & 38.87 & $\begin{array}{c}38.28 \\
(10.63 \%)\end{array}$ \\
\hline $\begin{array}{l}T_{4} \text { Stale seed bed + reduced } \\
\text { spacing up to }(25 \%)+\text { mulching } \\
\text { with wheat straw + one hand } \\
\text { weeding }\end{array}$ & 86.24 & 80.09 & 83.16 & 42.38 & 44.43 & $\begin{array}{c}43.40 \\
(25.43 \%)\end{array}$ \\
\hline $\begin{array}{l}\text { T }_{5} \text { Locally available weed mulch }+ \\
1 \text { hand pulling }\end{array}$ & 87.40 & 88.57 & 87.98 & 47.06 & 47.35 & $\begin{array}{c}47.20 \\
(36.41 \%)\end{array}$ \\
\hline $\begin{array}{l}T_{6} \text { Incorporation of mustard oil } \\
\text { cake } 15 \text { days before sowing @ } \\
5 \mathrm{t} / \mathrm{ha}+1 \mathrm{HW}\end{array}$ & 127.46 & 94.42 & 110.94 & 54.78 & 53.78 & $\begin{array}{c}54.28 \\
(56.87 \%)\end{array}$ \\
\hline $\begin{array}{l}\text { T}_{7} \text { ITK treatment on weed control } \\
\text { practices by farmers as mulching } \\
\text { with leaf on mango }\end{array}$ & 85.30 & 73.16 & 79.23 & 35.01 & 34.20 & $\begin{array}{c}34.60 \\
(0.00 \%)\end{array}$ \\
\hline $\mathrm{S}_{\mathrm{E}} \mathbf{M} \pm$ & 1.69 & 6.22 & 3.95 & 3.02 & 2.15 & 2.58 \\
\hline CD at $5 \%$ & 5.19 & 19.11 & 12.15 & 9.28 & 6.60 & 7.94 \\
\hline
\end{tabular}

Figures in parentheses are $\%$ increase over $\mathrm{T}_{7}$ - farmers practice 
Table.4 Weed control efficiency, Net profit and B:C ratio under different weed control practices in organic production system

\begin{tabular}{|c|c|c|c|c|c|c|c|c|c|}
\hline \multirow[t]{2}{*}{ Treatment } & \multicolumn{3}{|c|}{ Weed control efficiency \% } & \multicolumn{3}{|c|}{ Net profit Rs/ha } & \multicolumn{3}{|c|}{$B: C$ ratio $R s / R s$} \\
\hline & $\begin{array}{l}\text { Year } \\
2017\end{array}$ & $\begin{array}{l}\text { Year } \\
2018\end{array}$ & Mean & $\begin{array}{l}\text { Year } \\
2017\end{array}$ & $\begin{array}{l}\text { Year } \\
2018\end{array}$ & Mean & $\begin{array}{l}\text { Year } \\
2017\end{array}$ & $\begin{array}{l}\text { Year } \\
2018\end{array}$ & Mean \\
\hline $\begin{array}{c}\text { T }_{1} \text { Two hand weeding } 25 \\
\text { and } 50 \text { DAT }\end{array}$ & 52.26 & 46.91 & 49.58 & 56965 & 77647 & 67306 & 2.16 & 2.35 & 2.25 \\
\hline $\begin{array}{c}\mathrm{T}_{2} \text { Cono weeder } 25 \mathrm{DAT}+ \\
\text { one } \mathrm{HW} \text { at } 50 \mathrm{DAT}\end{array}$ & 42.50 & 31.29 & 36.84 & 50669 & 54419 & 52544 & 2.05 & 1.97 & 2.01 \\
\hline $\begin{array}{c}\mathbf{T}_{3} \text { Inter cropping with } \\
\text { Dhaincha }\end{array}$ & 32.40 & 40.46 & 36.43 & 48769 & 43096 & 45932 & 2.18 & 1.94 & 2.06 \\
\hline $\begin{array}{c}\mathrm{T}_{4} \text { Stale seed bed }+ \\
\text { reduced spacing up to } \\
(25 \%)+\text { mulching with } \\
\text { wheat straw + one hand } \\
\text { weeding }\end{array}$ & 15.32 & 25.58 & 20.45 & 48321 & 46909 & 47615 & 1.97 & 1.86 & 1.91 \\
\hline $\begin{array}{c}T_{5} \text { Locally available weed } \\
\text { mulch }+1 \text { hand pulling }\end{array}$ & 27.52 & 12.43 & 19.97 & 62061 & 56732 & 59396 & 2.38 & 2.10 & 2.24 \\
\hline $\begin{array}{c}\mathrm{T}_{6} \text { Incorporation of } \\
\text { mustard oil cake } 15 \text { days } \\
\text { before sowing @ } 5 \mathrm{t} / \mathrm{ha} \\
+1 \mathrm{HW}\end{array}$ & 67.94 & 53.50 & 60.72 & -4435 & -10457 & -7446 & 1.03 & 0.92 & 0.97 \\
\hline $\begin{array}{l}\mathbf{T}_{7} \text { ITK treatment on weed } \\
\text { control practices by } \\
\text { farmers as mulching with } \\
\text { leaf on mango }\end{array}$ & 00.00 & 00.00 & 00.00 & 31262 & 32990 & 32126 & 1.72 & 1.71 & 1.71 \\
\hline
\end{tabular}




\section{Grain and straw yield}

The grain and straw yield of rice under the influence of different weed management practices in organic production have been given in Table 3 reveals that maximum rice yield $54.28 \mathrm{q} / \mathrm{ha}$ was recorded under incorporation of mustard oil cake $5 \mathrm{t} / \mathrm{ha}+1$ HW followed by two hand weeding at 25 and 50 DAT. These treatments gave $53 \%$ to $57 \%$ higher grain yield than farmers practice of mulching with mango leaves in rice field. It may be due to better weed control efficiency as compared to mulching with mango leaf. Similar trend in straw yield was also reported. Beneficial effect of mustard oil cake @5 $\mathrm{t} / \mathrm{ha}+1 \mathrm{HW}$ on rice was also reported by Islam et al., (2007).

\section{Weed control efficiency}

Weed control efficiency $60.72 \%$ was maximum under incorporation of oil cake 5 t/ha+1 HW followed by $49.58 \%$ in two hand weeding at 25 and 50 DAT (Table 4). Other weed control practices gave $19.97 \%$ to $36.84 \%$ weed control efficiency as compared to farmers practice of weed control as mulching with mango leaves.

\section{Net profit and B:C ratio}

The net profit of rice under different weed control practice in organic production system has been presented in Table 4. It is clear that net profit of Rs 67306/ha was maximum under $2 \mathrm{HW}$ at 25 and 50 DAT followed by Rs 59396/ha under locally available weed mulch $+1 \mathrm{HW}$ and hoeing through conoweeder at $25 \mathrm{DAT}+1 \mathrm{HW}$ at $50 \mathrm{DAT}$. Incorporation of mustard oil cake $5 \mathrm{t} / \mathrm{ha}+1 \mathrm{HW}$ was not found economical as compared to farmers practice of mulching with mango leaves. B:C ratio 2.25 was maximum under $2 \mathrm{HW}$ at 25 and 50 DAT followed by 2.24 under locally available weed mulch+1 HW. Other treatments of weed control like intercropping of dhaincha with rice in 1:3 row system and hoeing through conoweeder at $25 \mathrm{DAT}+1$ $\mathrm{HW}$ at 50 DAT gave $\mathrm{B}: \mathrm{C}$ ratio more than 2 . Rest of weed control treatments gave B:C ratio below 2 . The positive effect of $2 \mathrm{HW}$ was also reported by Ramamoorthy et al., (2009).

On the basis of above field experiment it is concluded that application of mustard oil cake $5 \mathrm{t} / \mathrm{ha}+1 \mathrm{HW}$ gave maximum grain yield of rice but was not found economical due to higher cost of oil cake. Two hand weeding at 25 and 50 DAT gave maximum net profit and $\mathrm{B}: \mathrm{C}$ ratio followed by mulching with locally available weed mulch @ 3 t/ha+1 HW as weed control treatment under organic production system. These treatments gave B:C ratio higher than 2 .

\section{References}

Annonymous.2017. Kharif Crop outlook: www.skymetweather.com

Bhan VM.1968. Influence of row spacing on upland paddy. IL Riso 17:149-154.

Islam MM, Anwar MP, Rahman MM and Islam AKMM.2007. Influence of mustard oil cake on the performance of fine rice $\mathrm{CV}$. Chinigura. International Journal of Bio-Research 3(6): 50-54.

Iwata F.1975. Heat unit concept of crop maturity. In physiological aspects of dryland agriculture. Ed. U.S. Gupta, Oxford and IBH publishing $\mathrm{CO}$, New delhi.

Mukherjee PK, Anindya Sarkar and Maity SK.2008. Critical period of crop-weed competition in transplanting and wetseeded kharif rice (Oryza sativa L.) under tarai conditions. Indian Journal of Weed Science 40 (3\&4): 147-152.

Nuttonson MY.1955. Wheat climate relationship and use of phenology in ascertaining the thermal and 
photothermal requirement of wheat. Am. Inst. Crop. Ecol. Washington D.C. pp 388.

Rao AN and Shetty SVR.1976. Some biological aspects of intercropping system on crop weed balance. Indian Journal of Weed Science 8: 32-34.

Ramamoorthy K, Radhamani S and Subbaain P.2009. Integrated weed management for the control of Trianthema portulacastrum $L$. in rainfed finger millet (Eleusine coracana L. Gaertn). Green farming 2(4): 221-223.

Sastry PSN and Chakravorty NVK.1982. Energy summation indices for wheat crop in India. Agril. Meteorol. 27: 4548.

Tarafdar JC, Tripathi KP and Mahesh Kumar.2008. Organic Agriculture, Science Publisher, Jodhpur, P.372.

\section{How to cite this article:}

Prajapat Rohit, Mishra Priyanka, B.M. Maurya and Kurmvanshi, S.M. 2019. Thermal Response of Scented Rice under Different Weed Management Practices in Organic Production System. Int.J.Curr.Microbiol.App.Sci. 8(03): 1833-1841. doi: https://doi.org/10.20546/ijcmas.2019.803.217 